症例

術中食道心ェコーにより診断し得た人工弁機能不全の 1 症例 山口大学第 1 外科

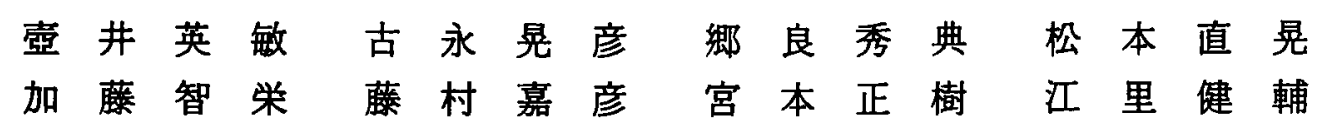

われわれは55墄男性, 僧房弁狭窄症の症例に対して Björk-Shiley 弁31mm を用い弁置 換術を施行した。人心肺より容易に離脱できたが, 体外循環終了後より, 一過性の低 血圧を生じるため経食道心ェコーを施行したところ，人工弁は時折閉鎖位に固定された 状態となる事が判明した。 この所見より stuck valve と判断し, 直ちに体外循環を開始 し，再弁置換術を施行した。術中所見より stuck valveの原因は判明しなかった。術後 経過は良好であった。現在われわれは術中原則的に食道心ェコーを施行しているが，そ の術中経食道心ェコーの有用性について若干の考察を行い報告した。

象引用語：食道心エコー, 弁置換術, Stuck valve

はじめに

近年弁疾患の手術の成績は非常に安定し向上してき た。 また人工弁も強度及び耐久性も良くなってきた。 しかし，不良弁ではなく，睷索等の外的要因による弁 機能不全の報告は散見され，再弁置換を余儀なくされ ることがある．最近われわれは僧帽弁狭窄症に対し， 弁置換術を施行し，弁機能不全を術中食道心エコーに より発見，直ちに再弁置換を行い良好な結果を得たの で報告する。

\section{症例}

患者: 55歳, 男性.

主訴：動悸。

既往歴: 肺結核 ( 5 藏頃).

現病歴：学童期より心雑音を指摘されていた。 1962 年頃より労作時に息切れが生じるよらになり，1963年 他院で直視下交連切開術を施行された。 その後症状は 軽快していたが，3 年前より労作時の動悸や時に起坐 呼吸も認めるよらになった（NYHA III）。精査扰よび 手術目的で当科入院となった。

入院時所見：身長 $158 \mathrm{~cm}$, 体重 $49 \mathrm{~kg}$ ，血压 $126 / 68$ torr, 脈拍 $66 / \mathrm{min}$ 不整. 聴診で心尖部に最強点を有す る diastolic rumbling murmurを聴取し，触診で肝炡 を 3 横指触知した。

入院時検査所見：血液生化学上異常はなかった。

1991年 2 月 14 日受付 1991 年 7 月 22 日採用
胸部 X 線写真は CTR $68 \%$, 右第 2 弓, 左第 3 弓, 4 弓の突出と左房陰影を認め, 肺は5っ血像を呈して いた（図 1).

心電図では af, RVH，心室性期外収縮の散発を認め た。

心蔵カテーテル検查では肺動脈楔入匟23torr, 肺動 脈压64/20 (35) torr, 右室圧65/7torr と上昇していた。 心拍出量低数は $3.161 / \mathrm{min} / \mathrm{m}^{2}$, 左室駆出率 $57 \%$ であっ た. 左室造影では僧帽弁の可動性は不良であった。

心エコー検査では僧帽弁は強く硬化し，腱索す短縮， 瘾合しており弁口面積1.1 1.2 $\mathrm{cm}^{2}$ で僧咱弁狭窄症の 所見があった。ささらに三尖弁閉鎖不全症も認めた。

以上の所見上り僧帽弁狭窄症, 三尖升閉鎖不全症の 診断で弁置換術, 三尖弁輪形成術を行らこととした。

手術: 胸骨正中切開を施行し, 大動脈送血, 上下大 静脈脱血による体外循環を開始した。大動脈根部より 心停止液を注入し，局所冷却も併用し心停止を得た。 右心房を切開し経中隔的に左房に到達した。僧帽弁は 強く硬化し，可動性不良で腱索も著明に短縮していた。 弁置換術の適応と考えた。弁を切除後, 径 $31 \mathrm{mmBjörk-}$ Shiley 弁を縫着した. major orificeは中隔側に向け た.人工弁の可動性は良好であることを確認し心房中 隔を閉鎖した。ささらに尖弁形成は Kay 法に準じて 行った。心拍動は容易に得られ体外循環より容易に離 脱できた。

しかしペースメーカーの併用も行っていたが, 術中 

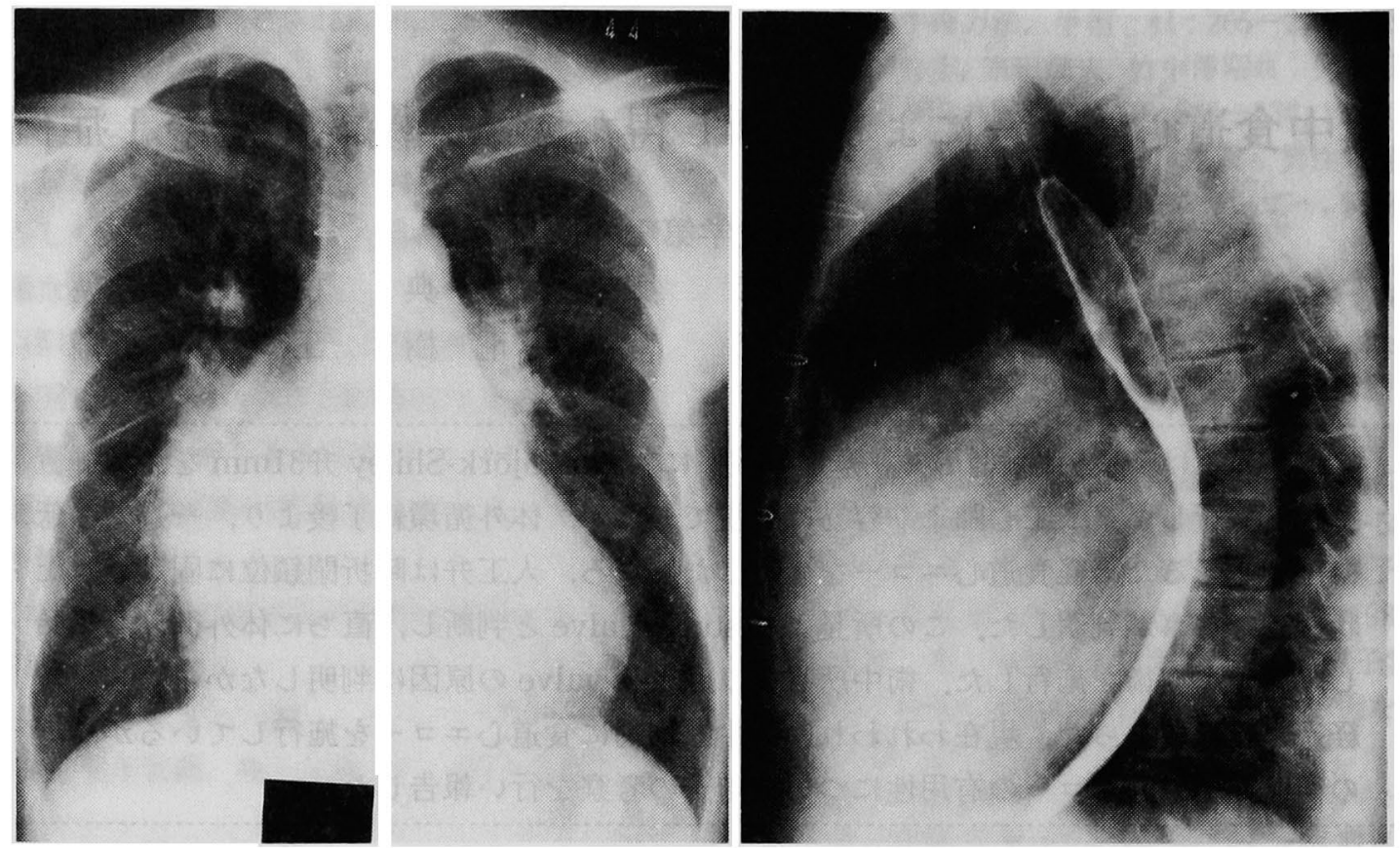

図 1 術前の胸写 : CTR 68\%, 左第 3 弓， 4 弓，右第 2 弓の突出, 左房の払大をみと める

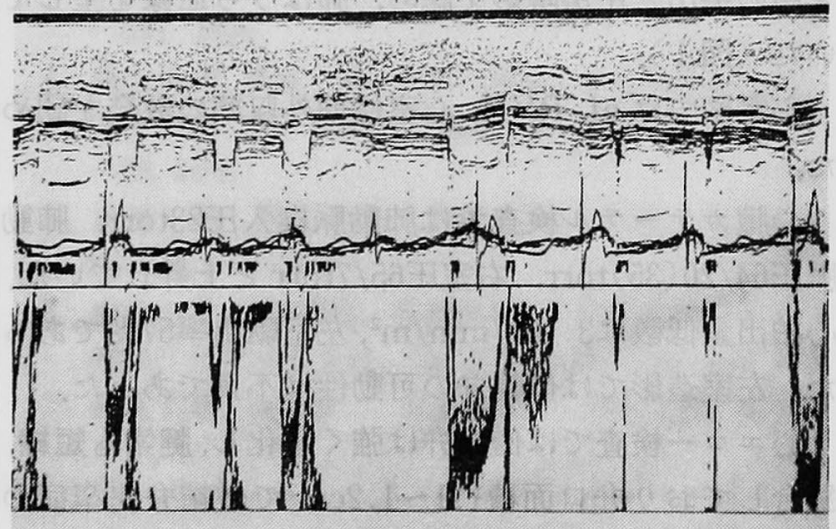

图 2 術中食道心エコー（stuck valve）：BjörkShiley valveがまったく開放しない心周期がみら れ, transmitral flow signal K異常がみられた。

心ェコーにより図 2 のごとく，弁が閉鎖位で時に固定 し開放しなくなることがあった。経過を観察している と，弁は閉鎖したまま，まったく開放しなくなった。 直ちに心マッサージを行いつつ体外循環を再開した。 心停止下に弁を観察し，用手的には弁は容易に開放し， 升開放を阻害する腱索や異物もなく弁自身にも問題が ないよ5に見えた. stuck valve の原因は不明であっ た、いずれにせよ移植弁の機能不全と判断しその弁を 切除し, 径 $27 \mathrm{~mm}$ Björk-Shiley 弁を再度縫着した。 major orificeは中隔側よりやや外側に向けたが開閉

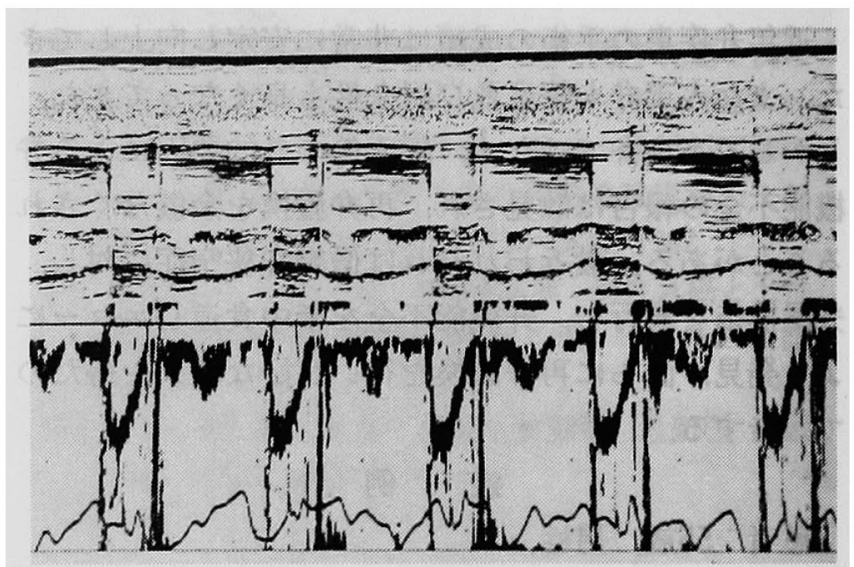

图 3 再弁置換後の食道心ェコー: Björk-Shiley弁 の開閉と flow は正常である

に問題はなかった。人工肺より容易に離脱できた。 再弁置換後の術中ェコーは図 3 のごとく，弁開放にる 異常なく transmitral flow す良好であった.

術後：術後経過も良好で，心ェューにおいても弁の 開放は良好であった(図 4 )。術後31日目に軽快退院し た.

\section{考察}

近年人工弁，中でも機械弁は改良され耐久性及び機 能に関して問題は少なくなってきた。しかし，その弁 に打いてもその機能不全の報告は散見される1) 6). 弁 機能不全は時に致死的となるためその発見と治療は重

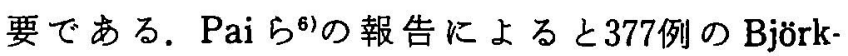




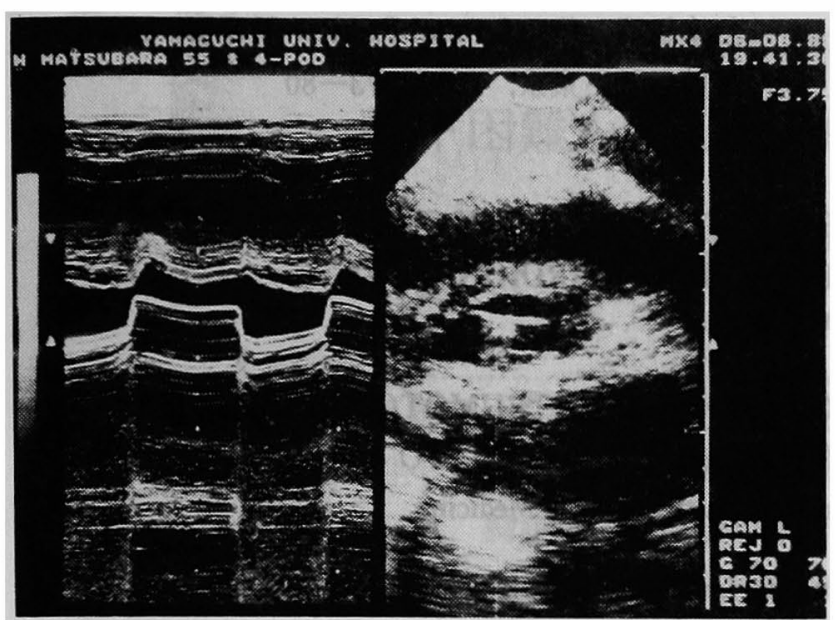

図4手術啳断層心エコー：手術後心エコー, 升の開 放は良好である

Shiley 弁と Medtronic-Hall 弁の使用経験中 5 例が弁 機能不全をきたしたと報告している。松木ら 23はその 原因を次のようにまとめている，大きく分けて器質的 原因と血流異常に起因する機能的原因である，器質的 原因として心臓構造物すなわち遺残弁組織, 乳頭筋, 腱索, 左室後壁などであり，心内異物として縫合系， カテーテルなどがある。慢性期では生体反応による pannus，血栓が弁機能障害の原因となる．諸家の報 告1)-6)でも縫合糸や腱索の迷入による原因が多くみら れるが，われわれの症例のように原因がはっきりしな い症例の頻度も高い。

Pai らの゙は stuck valveを避けるように次のよらに 警告している。まず tilting-disc prosthetic valve には 弁が動かなくなるといら事があると十分知っておく 事. 大きすぎる弁はさける.すなわち Björk-Shiley 弁 の29，31，33mmに扔いては血行動態的には差がない ので小さな弁で十分である．弁置換時に十分腱索を切 り縫合系の結目を弁輪よりできるだけはなし縫合糸を 短く切る事が大切である. 場合により monofilament 糸に上る連続縫合を行う，人工并縫着後には弁の開閉 をよく確かめ, 人工心肺離脱時, 離脱後も弁の開放音 と血行動態より弁機能に注意を厸わなくてはいけない と報告している.今回われわれは $31 \mathrm{~mm}$ の弁を用いた。 この大きすぎた弁す stuck valveの原因と考えられ る. Pai $5^{6}$ の言 5 様に血行動態的に $31 \mathrm{~mm}$ の弁は必要 なかったと考えられる。

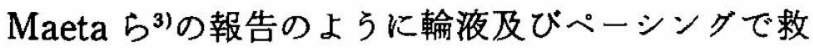
命した報告むあるが，いずれにしても術中，術直後に ほとんどの症例が発見されており，この時期でのより
正確な診断と再弁置換術が予後を決定するものと考光 る. 松木 ${ }^{21}$ は術後の心エコーで, 田中5) は術中心エコー で弁機能不全を発見したと報告している。最近われわ れは術中ルーチンとして食道心ェコーにより術前, 術 中, 術後の心機能をモニターしている. 松崎7は食道心 エコーは術中の操作中も手術手技になんら影響を及ぼ す事なく常時モニターができ，僧帽弁逆流などの僧帽 弁診断に有用であると報告している。体外循環中，特 に人工心肺からの離脱期の心機能, volume モニター などに非常飞有用であり, われわれは術中食道心エ コーを用いる事により安心して人工心肺からのよりス ムーズな離脱ができるようになった，本治験例のごと く，人工心肺離脱直後の閉鎖位で stuck した人工升の 状態を血圧波形からは心房細動による血流異常のため と考劣ていたが，食道心エコーで弁自体に原因がある 弁機能不全と判明した事により，すばやく再弁置換を 行い救命できたと考兄ている。

\section{結 語}

術中食道心ェコーにより僧帽弁位の Björk-Shiley 弁機能不全を発見し再弁置換による救命した症例を報 告するとともに，術中食道心ェコーの有用性を報告し た。

\section{文献}

1）桜田 徹, 栗林良正, 関根智之他：Björk-Shiley Monostrut 弁の臨床成績一捜入直後 struck valve への警鐘一，日心外会誌 $20: 95-97,1990$

2）松木修，鬼頭義次，小原邦義他：僧帽升位 Björk-Shiley Monostrut Type Valve の外因性人 工弁機能不全一 3 例の経験から一, 日胸外会誌 $36: 384-389,1988$

3) Maeta H, Jikuya T, Terada $Y$, et al: Acute but intermittent sticking of a Björk-Shiley mitral valve in closed position. Jpn Heart J 26 : 879-884, 1985

4) Blasco EC, Plzak LF, Sohn M, et al: Acute, complete, extrinsic obstruction of the BjörkShiley valve in the immediate postoperative period. J Thorac Cardiovasc Surg $86: 630-631$, 1983

5）田中 稔, 阿部稳雄, 村瀬允也他：僧帽弁位に用い た弁機能不全の術中心エュー図法に上る診断, 日 胸外会誌 $36: 541-545,1988$

6) Pai GP, Ellison RG, Rubin JW, et al: Disc immodilization of Björk-Shiley and medotronic hall valve during and immediately after valve 
replacement. Ann Thorac Surg $44: 73-76,1987$

7）松崎益徳, 楠川禮造：経食道心エコードブラー法.
杉本佰明, 他. Annual Review 循環器, 1990, 中 外医学社, 東京, 1990, p73-80

\title{
INTRAOPERATIVE DETECTION OF DISC IMMOBILIZATION OF BJÖRK-SHILEY VALVE BY TRANSESOPHAGEAL TWO-DIMENSIONAL ECHOCARDIOGRAPHY -REPORT OF A CASE-
}

\author{
Hidetoshi TSUBOI, Akihiko FURUNAGA, Hidenori GOHRA, Naoaki MATSUMOTO, Tomoe KATO, \\ Yoshiaki FUJIMURA, Masaki MIYAMOTO and Kensuke ESATO \\ First Department of Surgery, Yamaguchi University School of Medicine
}

Using Björk-Shiley valve $(31 \mathrm{~mm})$, mitral replacement was performed in a case of mitral stenosis in a 55 -yearold man. The patient could be easily freed from pump-oxygenator, however developed a trnasient hypotension immediately after weaning of extracorporeal circulation. Transesophageal two-dimentional echocardiography revealed disc immobilization. Stuck valve was considered, and extracorporeal circulation was started again, reimplantation being carried out. Postoperative course was uneventful.

As a rule, we perform transesophageal two-dimentional echocardiography during and immediately after valve replacement. Here some discussion of the usefulness of the procedure is presented. 